\title{
Spatial and temporal variability in the condition of postlarval and juvenile Penaeus plebejus sampled from a population subjected to pilot releases
}

\author{
Faith Ochwada-Doyle ${ }^{1,2, *}$, Charles A. Gray ${ }^{2}$, Neil R. Loneragan², \\ Matthew D. Taylor ${ }^{1,2,4}$, Iain M. Suthers ${ }^{1,4}$ \\ ${ }^{1}$ Evolution \& Ecology Research Centre, School of Biological, Earth and Environmental Science, \\ University of New South Wales, New South Wales 2052, Australia \\ ${ }^{2}$ Cronulla Fisheries Research Centre, NSW Industry and Investment, PO Box 21, Cronulla, New South Wales 2230, Australia \\ ${ }^{3}$ Centre for Fish \& Fisheries Research, School of Biological Sciences and Biotechnology, Murdoch University, South St, \\ Murdoch, Western Australia 6150, Australia \\ ${ }^{4}$ Sydney Institute of Marine Science, Building 22, Chowder Bay Road, Mosman, New South Wales 2088, Australia
}

\begin{abstract}
The potential for hatchery-release programs to augment the harvest rates of fisheries can be limited by environmental factors associated with survival, growth and body condition among released individuals. We assessed spatial and temporal variability in the condition of postlarval and small juvenile (1-10 mm carapace length) eastern king prawns Penaeus plebejus Hess sampled from an estuarine population subjected to pilot releases of 3 million postlarvae per year in southeastern Australia. Variability in the length-weight relationship was used as a measure of condition and compared between (1) autumn/winter and spring/summer periods and (2) bare and macrophytic habitats for $P$. plebejus sampled from a population in a closed estuarine system. At a reference carapace length of $3.97 \mathrm{~mm}$, condition was $\sim 14 \%$ higher for individuals sampled from bare habitat and $\sim 16 \%$ higher for those sampled during autumn/winter compared, respectively, with individuals sampled within macrophytic habitat and during spring/summer. Further experimental work on the factors investigated here is encouraged to increase our understanding of the environmental characteristics and mechanisms that lead to improved condition and thus persistence of stocked populations of $P$. plebejus.
\end{abstract}

KEY WORDS: Stock enhancement · Fisheries management · Habitat - Season · Prawns · Penaeid • ICOLL

Resale or republication not permitted without written consent of the publisher

\section{INTRODUCTION}

The widespread problems of overexploitation, recruitment limitation and habitat loss in marine environments are often addressed using 3 types of management interventions: reduction of fishing effort, restoration of habitat and/or stock enhancement (Ludwig et al. 1993, Blankenship \& Leber 1995, Hilborn 2007). The latter is often preferred because of its potential to increase faunal abundance without restricting fishery harvest (Travis et al. 1998, Rogers et al. 2010). Stock enhancement strictly refers to the release of large numbers of hatchery-reared larvae or juveniles into the wild to increase yields beyond levels supported by natural recruitment (Bell et al. 2006, 2008). In stock enhancement, releases may be combined with relatively high levels of fishing effort, thereby enabling fishery harvests to be sustained by a combination of natural recruitment and direct recapture of stocked animals (Bell et al. 2006). Interest in stock enhancement has increased greatly in the last $15 \mathrm{yr}$ because of new aquaculture technologies that enable production of large numbers of high quality postlarvae and juveniles (Leber 2002). 
Although there are examples of successful stock enhancement programs (e.g. Leber \& Arce 1996, McEachron et al. 1998, Zeimann 2003), some have been shown to impact negatively on receiving communities (e.g. Hilborn \& Eggers 2000, Araki \& Schmid 2010) and many have been considered economic failures because of poor longevity of enhanced populations and a consequent inability to supplement exploited populations (Blankenship \& Leber 1995, Bell et al. 2005). For example, analysis of catch-and-release histories for Penaeus japonicus in Japan suggested that hatchery releases did not succeed in augmenting total production of this species (Hamasaki \& Kitada 2006). In another instance, analysis of fishermen's log books following the release of postlarval and juvenile Homarus gammarus failed to show any evidence of successful enhancement of the species' stocks (Addison \& Bannister 1994).

The short-lived nature of many enhanced populations is often attributed to a poor understanding of the spatial and temporal environmental factors associated with maximum survival, growth and body condition among released individuals (Crowl et al. 1992, Einum \& Fleming 2001). This has resulted in the indiscriminate release of many species into habitats and ecosystems that do not complement their seasonal and spatial requirements across critical life history stages (Leber 2002, Taylor et al. 2009). Investigations of the most appropriate release strategies and long-term monitoring programs can significantly improve the success of stock enhancement efforts by defining the factors associated with the long-term persistence of released animals. Here, we aim to compare body condition between different seasonal groups and habitats for postlarval and juvenile Penaeus plebejus Hess sampled from populations subjected to pilot releases of hatchery-reared individuals.

Penaeus plebejus is a current candidate for largescale stock enhancement in parts of southeastern Australia (Taylor 2010). With an annual commercial market value of $\sim$ AUS\$40.5 million and a substantial recreational fishery (Courtney et al. 2002, Reid \& Montgomery 2005, Ives \& Scandol 2007), this species is one of the most economically important penaeid species within the region. As for other penaeids (e.g. Rothlisberg et al. 1999), stock enhancement of $P$. plebejus has been proposed as a tool that may augment fishery harvest rates and reduce fluctuations in catch caused by variable recruitment. Stock enhancement of penaeids in different parts of the world has, however, had varied success (Su \& Liao 1999, Bell et al. 2005, Loneragan et al. 2006, Wang et al. 2006). A clearer understanding of the species-specific relationships between environmental variables and indices of survival, body condition and growth is crucial to the development of successful enhancement programs for penaeids (Loneragan et al. 2004, 2006).
Morphometric indices of body condition such as Fulton's $K$ and Le Cren's condition factor are often used to quantify an animal's physical wellbeing and are thought to be useful complements to growth estimates (Choquenot 1991, Murphy et al. 1991, Rochet 2000). Furthermore, condition itself is considered to be correlated with survival in some species (e.g. Penaeus merguiensis; Staples \& Heales 1991). Fisheries scientists commonly use indices of condition derived from the morphometric relationship between body weight and length based on the hypothesis that heavier individuals of a given length may allocate energy more efficiently than lighter individuals and may therefore be in better physical health in terms of the condition of their body (e.g. Garcia-Berthou \& Moreno-Amich 1993, Teikwa \& Mgaya 2003, Froese 2006). However, problems with the use and calculation of morphometric condition indices are well documented and include violation of the important assumption of isometric growth when using Fulton's K (Garcia-Berthou \& Moreno-Amich 1993). Variability in the ratio $K$ is also often higher than variability in weight and length, the parameters compounded into this ratio (GarciaBerthou \& Moreno-Amich 1993, Suthers 1998).

Direct assessment of variation in the length-weight $(\mathrm{L}-\mathrm{W})$ relationship provides a more representative estimate of physical wellbeing than a condition index per se and this approach has been successfully applied for different species of fish (e.g. Filbert \& Hawkins 1995, Meretsky et al. 2000). For prawns, assessment of variation in the L-W relationship has been used to compare different groups of prawns or individuals exposed to different environmental characteristics (e.g. Bishara 1976, Cheng \& Chen 1990, Gab-Alla et al. 1990, Primavera et al. 1998, Okayi et al. 2010). Variation in the L-W relationship has also been used to assess differences in condition among prawns (e.g. Staples \& Heales 1991, Enin 1994, Pérez-Castañeda \& Defeo 2002, Teikwa \& Mgaya 2003, Araneda et al. 2008). Although this technique has been widely applied to penaeids, Primavera et al. (1998) showed that the L-W relationship of Penaeus monodon can differ with size and found differences in this relationship between individuals with a carapace length (CL) of $\sim 2-10,18-50$ and $40-70 \mathrm{~mm}$. In addition, higher growth rates in small penaeids compared with large penaeids can lead to more frequent moulting (Staples \& Heales 1991) and distort analyses of the L-W relationship when individuals from highly disparate size classes are examined together. Inferences on condition based on analyses of the L-W relationship should therefore be limited to individuals of similar sizes. Here, analyses of variation in the L-W relationship are extended, for the first time, to examine environmental variability in the condition of postlarval and small juvenile Penaeus plebejus (1-10 mm CL; 
Young 1978, Rothlisberg et al. 1995) sampled from populations subjected to pilot stock enhancement releases.

This study aimed to examine postlarval and small juvenile Penaeus plebejus from a population assumed to consist of released individuals only in a closed estuarine system and $P$. plebejus from a population assumed to consist of released and wild individuals in an intermittently open system. For postlarval and juvenile $P$. plebejus sampled from each population, we attempted to analyze variation in the $\mathrm{L}-\mathrm{W}$ relationship to compare relative condition in (1) autumn/winter and spring/summer periods, and (2) bare and macrophytic habitats. These comparisons may provide information on the environmental characteristics associated with maximum body condition in postlarval and juvenile $P$. plebejus, which may be useful for refining release strategies for $P$. plebejus.

\section{MATERIALS AND METHODS}

Pilot releases and sampling. Penaeus plebejus postlarvae were released into 2 coastal lakes located in New South Wales (NSW), Australia: Wallagoot Lake $\left(36.7883^{\circ} \mathrm{S}, 149.9419^{\circ} \mathrm{E}\right)$ and Back Lake $\left(36.8825^{\circ} \mathrm{S}\right.$, $149.9230^{\circ} \mathrm{E}$ ). There were 2 release periods in each lake, the first period was in January 2007 and the second was in December 2007. Wallagoot Lake (area $\sim \mathrm{km}^{2}$, maximum depth $\sim 8 \mathrm{~m}$, mean \pm SE depth across lake's study sites $2.43 \pm 0.40 \mathrm{~m}$ ) had been closed to the ocean for $\sim 11 \mathrm{yr}$ prior to the releases owing to a large entrance berm ( $150 \mathrm{~m}$ in width) that had withstood severe storms and high rainfall or flood events (D. Reckord pers. comm.). Because of this lake's elongated closure and its closure throughout this study, we assumed that Wallagoot Lake had not had any natural recruitment of $P$. plebejus because this species spawns in oceanic waters with postlarvae relying on open corridors into lakes and estuaries to access shallow nursery habitats for early development (Ruello 1975, Young 1978, Reid \& Montgomery 2005). Although comprehensive presampling was not conducted in Wallagoot Lake, the assumption that there were no naturally occurring $P$. plebejus in the lake was supported by our own preliminary small-scale sampling and anecdotal reports from local recreational fishermen targeting prawns in Wallagoot Lake, which indicated that $P$. plebejus had not been caught in this lake since 2002 (G. Liddell pers. comm.). Prior to its closure to the ocean, Wallagoot Lake supported a recreational fishery for wild P. plebejus (G. Liddell pers. comm.) and stock enhancement is a tool that may establish a put-grow-take recreational fishery in this recruitment-limited system.

Back Lake is a smaller intermittently open lake (area $\sim 0.8 \mathrm{~km}^{2}$, maximum depth $\sim 4 \mathrm{~m}$, mean $\pm \mathrm{SE}$ depth across lake's study sites $0.7 \pm 0.2 \mathrm{~m}$ ) that experiences natural, albeit variable, recruitment of Penaeus plebejus. In this lake, stock enhancement may increase the recreational harvest rates of $P$. plebejus during periods of low recruitment. During the course of this study, Back Lake opened to the ocean on 3 occasions in 2007 and twice in 2008. It is therefore possible that wild $P$. plebejus as well as other species of prawns recruited naturally into this lake during the study. It is also likely that some released individuals emigrated from this lake.

Bare sandy and muddy habitats are some of the most prevalent habitat types in Wallagoot Lake (total area of bare habitat $\sim 3.12 \mathrm{~km}^{2}, \sim 78 \%$ of lake area) and Back Lake (total area of bare habitat $\sim 0.56 \mathrm{~km}^{2}$, $\sim 70 \%$ of lake area) (NSW Department of Natural Resources 2000). Macrophytic beds are also prevalent in both lakes and include Halophila spp., Zostera capricorni and Ruppia spp. in Wallagoot Lake (total area of macrophytic habitat $\sim 0.77 \mathrm{~km}^{2}, \sim 19 \%$ of lake area) and Z. Capricorni and Ruppia spp. in Back Lake (total area of macrophytic habitat $\sim 0.22 \mathrm{~km}^{2}, \sim 27 \%$ ) (NSW Department of Natural Resources 2000). These habitats are representative of the types of habitats found in most southeastern Australian estuarine lagoons (Roy et al. 2001).

Penaeus plebejus were produced in a commercial hatchery (Rocky Point Aquarium, Gold Coast, Australia) using wild brood-stock collected off central eastern Australia (between $30.2802^{\circ} \mathrm{S}, 153.2016^{\circ} \mathrm{E}$ and $24.7516^{\circ} \mathrm{S}, 153.0227^{\circ} \mathrm{E}$ ), where wild populations of $P$. plebejus are believed to spawn throughout most of the year (Montgomery 1990). After hatching, individuals were reared in the hatchery for 18 to $20 \mathrm{~d}$ to a mean $( \pm \mathrm{SE}) \mathrm{CL}$ of $2.48 \pm 0.13 \mathrm{~mm}$ for the first release and $2.54 \pm 0.22 \mathrm{~mm}$ for the second release. During this rearing period, individuals were held in 400001 parabolic fiberglass tanks at densities of 200000 individuals (ind.) $\operatorname{tank}^{-1}$ and were fed hatchery pellets $\left(1.5 \mathrm{ltank}^{-1} \mathrm{~d}^{-1}\right)$.

Two days before transportation (while still in the hatchery), postlarval Penaeus plebejus were acclimated to the water conditions (dissolved oxygen $\left[\mathrm{mg} \mathrm{l}^{-1}\right]$, temperature $\left[{ }^{\circ} \mathrm{C}\right]$ and salinity) of Wallagoot and Back Lakes and then transported to the lakes in 101 of water within sealed plastic bags, packed inside foam boxes. During each release period, $\sim 3$ million ind. were released into Wallagoot Lake and $\sim 1$ million ind. were released into Back Lake. This equates to a stocking density of $\sim 1$ postlarvae $\mathrm{m}^{-2}$ in Wallagoot Lake and 1.3 postlarvae $\mathrm{m}^{-2}$ in Back Lake. For each of the 2 release periods in Wallagoot Lake, releases of $\sim 1$ million ind. $\mathrm{d}^{-1}$ took place on 3 separate days. For the first release period in Back Lake, releases of $\sim 500000$ ind. $\mathrm{d}^{-1}$ took place on 2 separate days. During 
the second release period in Back Lake, $\sim 1$ million ind. were released on a single day. Postlarvae were released into the shallow periphery (water depth 1-2 m) of each lake into bare and macrophytic habitats. The stage at which individuals were released in the present study was chosen based on the stage at which penaeids in Japan (Kurata 1981), China (Liu 1990), Kuwait (Farmer 1981) and Sri Lanka (Davenport et al. 1999) were previously released. Water conditions within each estuary during the releases are summarized in Table 1a. No attempts to reduce predation were made during releases in either lake (e.g. release into mesocosms or removal or potential predators prior to release).

Postlarval and juvenile Penaeus plebejus were sampled from 2 bare sites and 2 macrophytic habitat sites in each of Wallagoot and Back Lakes by towing an epibenthic sled $(0.8 \times 0.45 \mathrm{~m}$ opening with $2 \mathrm{~mm}$ stretch mesh; towed for $2 \mathrm{~min}$ at a speed of $\sim 0.5 \mathrm{~m} \mathrm{~s}^{-1}$ ) over an area of $\sim 50 \mathrm{~m}^{2}$. This sampling regime was conducted from January 2007 to January 2009 on every third night during the first fortnight after each release, then once a month for $3 \mathrm{mo}$, and every second month thereafter. Three replicate tows using the epibenthic sled were attempted in each site at each sampling time. Sampling was carried out at night and during the darkest part of the lunar cycle (the new moon), which is when many penaeid species, including $P$. plebejus, emerge into the water column (Wassenberg \& Hill 1994, Rothlisberg et al. 1995, Griffiths 1999, Vance \& Pendrey 2008).

Samples were frozen $\sim 4 \mathrm{~h}$ after collection and later sorted in the laboratory and examined under a dissecting microscope to identify Penaeus plebejus individuals. Each P. plebejus was blotted dry and then measurements of CL and wet weight $(W)$ were taken to the nearest $0.01 \mathrm{~mm}$ and $0.001 \mathrm{~g}$, respectively. Temperature, dissolved oxygen and salinity measurements were also recorded for each lake on several occasions throughout the study ( $50 \%$ of the sampling trips) using a Hydrolab water quality meter (DataSonde ${ }^{\circledR} 4$, Surveyor 4 Display; HACH Environmental) during the first half of the study, and a Yeo-Kal water quality meter (Yeo-Kal Electronics) for the remainder of the study. Owing to repeated failures by both apparatuses used to measure water conditions, we were unable to include water conditions in any analyses.

Analysis of variation in condition between habitats and seasonal groups. All statistical analyses were carried out using the open-source statistical package $\mathrm{R}$ (Ihaka \& Gentleman 1996). We attempted to use a 2 -way ANCOVA $(\alpha=0.05)$ to test for differences in the L-W relationship of Penaeus plebejus sampled from the different habitats and during the different seasonal groups within each of the lakes. The logarithm of observed $W$ was the dependent variable, the logarithm of observed CL was the covariate, and habitat and seasonal group were the main factors. All levels of each factor were fixed and can be summarised as (1) habitat, macrophytic (M) or bare (B); and (2) seasonal group, autumn/winter (AW: 1 March-31 August) or spring/ summer (SS: 1 September-29 February). Seasons (i.e. spring, summer, autumn and winter) were combined into broader seasonal groups because insufficient individual $P$. plebejus were collected within some of the distinct seasons for valid analysis.

For Back Lake, very few postlarval and small juvenile Penaeus plebejus were sampled within some levels of the factors seasonal group (SS: $\mathrm{n}=12, \mathrm{AW}: \mathrm{n}=$ 80 ) and habitat (B: $n=19, M: n=73$; Table 2), precluding meaningful statistical analyses using data sampled from this lake. For Wallagoot Lake, the statistical assumptions of ANCOVA that regressions were homogenous among levels of each factor and that the dependent variable and covariate had a linear relationship among the levels of each factor were tested, respectively, before each main ANCOVA by (1) using a preliminary full ANCOVA $(\alpha=0.05)$ that analyzed the factor by covariate interaction terms (which, if significant, indicated heterogeneity) (Garcia-Berthou \& Moreno-Amich 1993, Quinn \& Keough 2002) and (2) examining the relationship between the covariate and dependent variable at each level of each factor using scatter graphs (Quinn \& Keough 2002). To limit covariate dependence on levels within factors, observations that had unusually high or low val- b) Seasonal group

$\begin{array}{lllll}\text { Wallagoot } & \text { Autumn/winter } & 7.9 \pm 0.29 & 16 \pm 3.71 & 36.7 \pm 0.45 \\ & \text { Spring/summer } & 7.7 \pm 0.38 & 25 \pm 4.20 & 36.6 \pm 0.38 \\ \text { Back } & \text { Autumn/winter } & 7.5 \pm 0.31 & 18 \pm 4.23 & 34.1 \pm 0.61 \\ & \text { Spring/summer } & 7.8 \pm 0.24 & 23 \pm 4.81 & 35.7 \pm 0.26\end{array}$

$\begin{array}{ccc}8.1 \pm 0.09 & 26 \pm 0.47 & 36.2 \pm 0.17 \\ 7.6 \pm 0.03 & 25 \pm 0.27 & 37.8 \pm 0.14 \\ 8.4 \pm 0.06 & 24 \pm 1.15 & 34.5 \pm 0.23 \\ 8.9 & 25 & 32.7 \\ & & \\ 7.9 \pm 0.29 & 16 \pm 3.71 & 36.7 \pm 0.45 \\ 7.7 \pm 0.38 & 25 \pm 4.20 & 36.6 \pm 0.38 \\ 7.5 \pm 0.31 & 18 \pm 4.23 & 34.1 \pm 0.61 \\ 7.8 \pm 0.24 & 23 \pm 4.81 & 35.7 \pm 0.26 \\ & & \end{array}$


Table 2. Total number of tows conducted to sample Penaeus plebejus using an epibenthic sled in bare and macrophytic habitats within Wallagoot and Back Lakes. Also shown are the number of tows with P. plebejus and the total number of postlarval and small juvenile $P$. plebejus retained for measurement

\begin{tabular}{|lcccc|}
\hline Lake & Habitat & $\begin{array}{c}\text { Total no. } \\
\text { of tows }\end{array}$ & $\begin{array}{c}\text { No. of } \\
\text { tows with } \\
\text { P. plebejus }\end{array}$ & $\begin{array}{c}\text { No. of } \\
\text { P. plebejus } \\
\text { retained }\end{array}$ \\
\hline Wallagoot & $\begin{array}{c}\text { Bare } \\
\text { Macrophytic }\end{array}$ & 140 & 49 & 78 \\
Back & 122 & 54 & 418 \\
& $\begin{array}{c}\text { Bare } \\
\text { Macrophytic }\end{array}$ & 133 & 9 & 19 \\
& 142 & 5 & 73 \\
\hline
\end{tabular}

ues were omitted so that the range of covariate values was similar among all levels (Quinn \& Keough 2002).

The predicted mean weight $(P W)$ of postlarval and juvenile Penaeus plebejus from Wallagoot Lake was calculated as a numerical measure of the condition of individuals with a mean CL. PW was calculated for each level of each factor (Pérez-Castañeda \& Defeo 2002) using the power function:

$$
P W=10^{a} \times \mathrm{CL}^{b}
$$

where CL was the mean $( \pm \mathrm{SE}) \mathrm{CL}(3.97 \pm 0.07 \mathrm{~mm})$ and the coefficients $a$ and $b$ were calculated from the equation:

$$
\log W=\log _{10} a+b\left(\log _{10} \mathrm{CL}\right)
$$

where $a$ and $b$, respectively, represent the vertical intercept and slope of the linear relationship between the observed $\log _{10} \mathrm{CL}$ and $\log _{10} W$ measurements for each level of each factor.

We attempted to assess differences in growth for the Penaeus plebejus collected for which size (CL) at day zero (date of release) could be confidently estimated. This could only be done for individuals sampled from Wallagoot Lake before the third month after the second release. Evaluation of differences in growth rate across habitat and seasonal groups was attempted using a 2-way ANCOVA $(\alpha=0.05)$ to test for spatiotemporal differences in the linear relationship between $\mathrm{CL}$ and time since release. However, the growth of the individuals intended for analysis could not be modeled accurately using a linear relationship $\left(\mathrm{R}^{2}\right.$ values ranged from 0.12 to 0.34 ). Non-linear power relationships were also unable to adequately model growth $\left(\mathrm{R}^{2}\right.$ values ranged from 0.04 to 0.39 ). We were therefore unable to assess variability in growth between habitats and seasons.

\section{RESULTS}

With the exception of temperature, which showed some seasonal fluctuations, average water conditions did not show marked variation during the study (Table 1b). From a total of 537 deployments of the epibenthic sled during the $2 \mathrm{yr}$ sampling period, only 117 of these tows contained any Penaeus plebejus (Table 2). A total of 687 P. plebejus were captured in the epibenthic sled during the study and of these, 588 were retained for measurement because they had intact bodies with paired W and CL measurements and were classified as postlarval or small juvenile $P$. plebejus (CL = 1-10 mm; Young 1978, Rothlisberg et al. 1995). Of the 117 tows with $P$. plebejus, 85 contained fewer than 5 individual prawns irrespective of the habitat, lake or season in which they were conducted. Even tows conducted immediately after the releases yielded very low numbers of prawns (the mean [+SE] number of $P$. plebejus sampled per tow in the first month after releases 1 and 2 was $4.25 \pm 0.89$ and $2 \pm 0.38$ ind. tow ${ }^{-1}$, respectively). This was despite our visual observation of numerous prawns in the water column during much of the study period. This precluded calculation of representative estimates of survival that could be used as an index of the success of the releases and compared between the different levels of each factor. Analyses of variation in condition were only attempted for data collected from Wallagoot Lake (Table 3). To ensure that covariate values were independent of the levels within each factor, only $P$. plebejus with a CL between 1.62 and $9.61 \mathrm{~mm}$ were retained for analysis.

Table 3. Penaeus plebejus. Summary of data for postlarvae and small juveniles sampled from a population of eastern king prawns in Wallagoot Lake following pilot releases and retained for analysis. The overall mean carapace length (CL) and weight for all postlarval and small juveniles $P$. plebejus sampled was $3.97 \pm 0.07 \mathrm{~mm}$ and $0.07 \pm 0.003 \mathrm{~g}$, respectively

\begin{tabular}{|lcrcrcr|}
\hline Factor & Level & $\mathrm{n}$ & \multicolumn{2}{c|}{ CL (mm) } & \multicolumn{2}{c|}{ Weight (g) } \\
& & & Range & Mean \pm SE & & Range \\
\hline Habitat & Macrophytic & 381 & $1.62-6.93$ & $4.01 \pm 0.07$ & $0.01-0.28$ & $0.07 \pm 0.002$ \\
& Bare & 78 & $1.90-9.61$ & $5.26 \pm 0.15$ & $0.02-0.83$ & $0.14 \pm 0.01$ \\
Seasonal group & Autumn/winter & 272 & $1.84-9.61$ & $4.82 \pm 0.07$ & $0.01-0.83$ & $0.10 \pm 0.01$ \\
& Spring/summer & 187 & $1.62-8.00$ & $3.35 \pm 0.09$ & $0.01-0.20$ & $0.05 \pm 0.002$ \\
\hline
\end{tabular}




\section{Variation in condition between habitats and seasonal groups}

For the full ANCOVA model used to analyse the data for postlarvae and small juvenile prawns sampled from Wallagoot Lake, a plot of the residuals versus the fitted values showed that residuals did not exhibit any systematic departures from zero, indicating a satisfactory fit of the model. The $\log _{10} \mathrm{CL}$ and $\log _{10} W$ values exhibited a satisfactory linear relationship at each level of each factor (Fig. 1). The preliminary full ANCOVA used to test the assumption of homogeneous regressions among levels of each factor showed that the 3 -way interaction term between $\log _{10} \mathrm{CL}$, habitat and seasonal group was not significant $(F=0.65, \mathrm{p}=0.42$, $\mathrm{df}=1)$. However, the interaction terms between $\log _{10} \mathrm{CL}$ and habitat $(F=26.17, \mathrm{p} \ll 0.01, \mathrm{df}=1)$ and $\log _{10} \mathrm{CL}$ and seasonal group $(F=166.94, \mathrm{p} \ll 0.01$, df $=$ 1) were highly significant. This violation of a critical assumption precluded further examination of the rest of the results from the ANCOVA (Underwood 2002).

Even so, the observed heterogeneity in regressions indicated that the effect of the different habitat and seasonal group treatments was to alter the slopes significantly (Underwood 2002) (i.e. the rate at which
Table 4. Penaeus plebejus. Predicted weights $(P W, g)$ of eastern king prawns from Wallagoot Lake with a carapace length of $3.97 \mathrm{~mm}$ discriminated by habitat and seasonal group. Also given are the slopes (mean $\pm \mathrm{SE}$ ) and vertical intercepts of each linear equation used to calculate $P W$

\begin{tabular}{|lccc|}
\hline $\begin{array}{l}\text { Habitat/seasonal } \\
\text { group }\end{array}$ & Slope & Vertical intercept & $P W$ \\
\hline Bare & $1.90 \pm 0.16$ & $-2.28 \pm 0.11$ & 0.07 \\
Macrophytic & $1.08 \pm 0.06$ & $-1.85 \pm 0.03$ & 0.06 \\
Autumn/winter & $2.10 \pm 0.07$ & $-2.49 \pm 0.05$ & 0.06 \\
Spring/summer & $0.45 \pm 0.08$ & $-1.55 \pm 0.05$ & 0.05 \\
\hline
\end{tabular}

$\log _{10} W$ increased per unit increase in $\log _{10}$ CL). Among habitats, the slope was significantly higher for postlarvae and juveniles sampled from bare habitat. Among seasonal groups, the slope was significantly higher for individuals sampled during autumn/winter. The condition (as estimated from $P W$ ) of individuals with a CL of $3.97 \mathrm{~mm}$ within the different levels of each factor reflected the same pattern because condition was slightly higher for individuals sampled from bare habitat than those sampled from macrophytic habitat, and slightly higher for individuals sampled during autumn/winter than those sampled during spring/summer (Table 4).
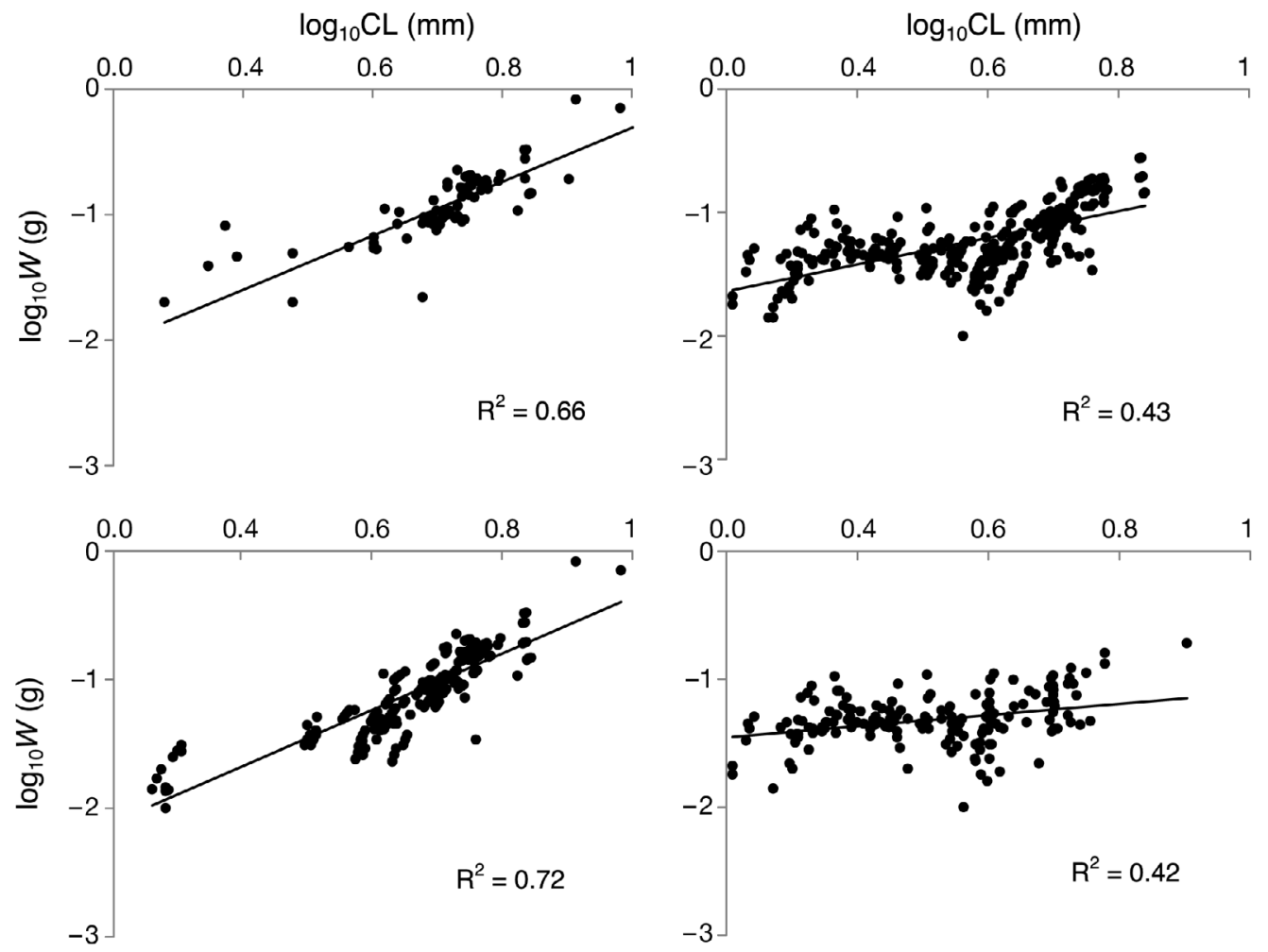

Fig. 1. Penaeus plebejus. Linear relationships between the logarithms of weight $(\mathrm{W}, \mathrm{g})$ and carapace length $(\mathrm{CL}, \mathrm{mm})$ for postlarval and small juvenile eastern king prawns (CL 1.62-9.61 mm) in Wallagoot Lake across different habitats and seasonal groups: (a) bare habitat, (b) macrophytic habitat, (c) autumn/winter and (d) spring/summer. The correlation of determination ( $\mathrm{R}^{2}$ ) for each linear model is also given 


\section{DISCUSSION}

This study was limited by the low rate at which Penaeus plebejus were recovered from both Wallagoot and Back Lakes. Given our visual observation of numerous prawns within the water column during many of the sampling trips and recaptures of large juvenile $P$. plebejus by recreational fishermen following the releases in Wallagoot Lake, the low recovery rates in individual tows were possibly caused by limited gear efficiency. Small trawls and epibenthic sleds, which have been previously used to sample penaeids (e.g. Young 1975, Moriarty 1977, Haywood \& Staples 1993, Loneragan et al. 1994), are limited in deeper waters because they often cannot sample $>0.6 \mathrm{~m}$ above the benthos. Future studies comparing condition, growth or survival of released $P$. plebejus among spatiotemporal factors should explore the standardised use of gear that can target most of the water column irrespective of depth such as trammel nets (e.g. Thomas et al. 2003) or higher-flying trawl or beam nets. However, because penaeid postlarvae are often benthic, these methods may need to be combined with more frequent sampling using gear that specifically targets benthic fauna.

Like many other studies, this research has shown that variation in the $\mathrm{L}-\mathrm{W}$ relationship of prawns can occur between different levels of environmental factors (Bishara 1976, Cheng \& Chen 1990, Primavera et al. 1998) and that this variation may be useful in assessing differences in condition among levels (Staples \& Heales 1991, Enin 1994, Pérez-Castañeda \& Defeo 2002, Teikwa \& Mgaya 2003). At the spatial and temporal scales examined here, condition of Penaeus plebejus belonging to an average size class was higher in bare habitat and during autumn/winter. Factors that may have contributed to these patterns are discussed below.

We predicted that seasonal differences in condition would be observed because of a direct association between condition and temperature. An animal's condition can be affected by temperature through its effects on whole organism metabolism and the rates of biochemical reactions (Ponce-Palafox et al. 1997, Gillooly et al. 2001). Low ambient temperatures will generally reduce metabolism in prawns (Haywood \& Staples 1993), and may therefore lower condition. Accordingly, Pérez-Castañeda \& Defeo (2002) found that peaks in the condition of Farfantepenaeus aztecus, $F$. brasiliensis and $F$. duorarum, as measured by the L-W relationship, coincided with warm temperatures. The condition of Penaeus merguiensis was also shown to be highest at $20^{\circ} \mathrm{C}$ and declined not only with decreasing temperatures, but also as temperatures approached $30^{\circ} \mathrm{C}$ and above (Staples \& Heales 1991).
The latter pattern was explained by more frequent moulting owing to a rapid increase in length at the highest temperatures accompanied by lower incorporation of protein into the body tissue (Staples \& Heales 1991). Bishara (1976) recorded seasonal variations in the L-W relationship of Metapenaeus stebbingi and M. monoceros and postulated that these variations were associated with spawning season because the rate of weight gain per unit of length gained was lowest at the peak of the spawning season. However, a direct association between spawning period and variation in the L-W relationship here is unlikely because there was no evidence of gonadal maturation in the postlarval and juvenile samples and the $P$. plebejus in Wallagoot Lake were not exposed to the environmental conditions usually associated with the onset of offshore spawning activity (Ruello 1975, Young 1978, Reid \& Montgomery 2005).

In the present study, the condition and overall rate of weight gain per unit of length gained were significantly higher during autumn/winter compared with spring/summer. This may be because individuals with the highest body condition were the ones able to survive through to autumn/winter after each release in Wallagoot Lake. If this was the case, these individuals may also have been faster growing and would have therefore been among the first to move out of the postlarval/small juvenile size class and into the $>10 \mathrm{~mm} \mathrm{CL}$ size class by each of the following spring/summer periods. However, it is difficult to evaluate this theory because of the absence of relative survival estimates and because the direct effect of temperature on the L-W relationship could not be rigorously assessed here. Furthermore, water temperatures within seasonal groups were nearly as variable as they were between seasonal groups in the present study, and this was probably a result of combining distinct seasons into broad seasonal groups. Although carefully designed manipulative experiments conducted over temporal scales of multiple years are necessary to monitor and definitively assess the relative influence of season on the condition and possibly survival of released Penaeus plebejus, shorterterm experiments (e.g. Staples \& Heales 1991) may enable us attribute differences in temperature to changes in this species' condition.

Macrophytic habitat was expected to be associated with the highest condition in Penaeus plebejus because, unlike bare habitat, it contains items such as seagrass foliage and epiphytes and may contain greater abundances of microalgae and microinvertebrates (Keough \& Downes 1982, Orth et al. 1984, Kneib 1987, Loneragan et al. 1997, Jackson et al. 2001). All of these items are typical components of the penaeid diet (Kitting et al. 1984, Suthers 1984, Wassenberg \& Hill 1987, Dall et al. 1990, Rothlisberg 1998). However, con- 
dition here was slightly higher in bare habitat. For Farfantepenaeus aztecus, F. brasiliensis and F. duorarum, individuals with the highest condition were similarly found to occur in habitats with lower seagrass cover (Pérez-Castañeda \& Defeo 2002). Although they did not examine the association between habitat and body condition, Young \& Carpenter (1977) showed that $P$. plebejus recruits were no more abundant on seagrasses than bare substrates, which may suggest that macrophytic habitats do not play an important role for this species. However, in a later study in the same geographical area, Young (1978) found that the abundance of $P$. plebejus was usually higher in seagrass habitats compared with adjacent bare habitats.

Because predation mortality in many penaeids, including Penaeus plebejus, has been shown to be lower in vegetated habitats compared with bare habitats (Hill \& Wassenberg 1993, Kenyon et al. 1997, Ochwada-Doyle et al. 2010), we suggest that higher predation rates in bare habitats here may have resulted in higher mortality for individuals with lower body condition (i.e. poorer health). Individuals that were in better condition and perhaps more capable of escaping from predators may have therefore been present within bare habitats at higher densities, leading to the observed pattern of higher condition in this habitat compared with macrophytic habitat. The presence of structure (the blades and leaves of macrophytes) within the macrophytic habitats may have protected most individuals from predation mortality irrespective of their condition. However, this study did not appropriately test the influence of habitat structure on predation mortality or condition. Carefully designed manipulative experiments are required to determine the habitats that will lead to maximum body condition among released $P$. plebejus.

It should be noted that the relatively small size of Wallagoot Lake may have allowed individuals to move between different habitats within short intervals of time. Although there is no definitive information on the maximum distance that postlarval and small juvenile Penaeus plebejus can traverse within nursery grounds over short periods of time, a previous 16 mo study reported that only $23.1 \%$ of postlarval $P$. plebejus were caught beyond $\sim 1 \mathrm{~km}$ from the sea within an estuary (Coles \& Greenwood 1983) and previous work has shown that once this species' postlarvae have settled within a preferred habitat during the day, they will rarely move out of this habitat to adjacent alternative habitats over a $12 \mathrm{~h}$ period (Ochwada et al. 2009). Bare and macrophytic habitats in the present study were separated by $\sim 1 \mathrm{~km}$. Together with the observed significant difference in condition between habitats, the spatial separation of the habitats suggests that the different habitats examined within Wallagoot Lake were sufficiently independent. However, the work by Ochwada et al. (2009) did show that postlarval P. plebejus forage between different adjacent habitats during the night and thus may be able to traverse large distances during the night time. Future studies in estuaries with larger $(>5 \mathrm{~km})$ spatial separation between habitats or pilot releases into mesocosms that can eliminate the possibility of inter-habitat movement are therefore necessary to facilitate a more thorough comparison of the condition of $P$. plebejus released directly into macrophytic habitat with that of individuals released into bare habitats.

\section{Implications for stock enhancement and conclusions}

Although low recovery rates restricted the applicability of this study's findings in developing release strategies for Penaeus plebejus, we did show that the condition of $P$. plebejus can vary with habitat and seasonal periods. Manipulative experiments examining the role of habitat (e.g. Ochwada et al. 2009, Ochwada-Doyle et al. 2010) and season in influencing the condition, growth or survival of $P$. plebejus are strongly encouraged for all systems targeted for stock enhancement. Future pilot releases aimed at properly evaluating the feasibility of supplementing a species through stock enhancement should also adopt a replicated beforeafter-control-impact experimental design wherein target systems are sampled prior to releases and unstocked systems with wild populations of the candidate release species are also sampled for comparison (e.g. Eggleston et al. 2008). Compared with pilot releases into only 1 or 2 systems, such designs would enable a more rigorous assessment of the environmental characteristics needed for successful stock enhancement and clearer identification of potential impacts of stock enhancement.

Acknowledgements. This work was completed as part of a $\mathrm{PhD}$ candidature and supported in part by grants from the New South Wales Recreational Saltwater Fishing Trust (no. L30), the Australian Research Council (no. LP0775000) and the New South Wales Department of Primary Industries. We thank D. Collins, G. Liddell, the Dulhunty family, D. Reckord, UNSW staff, Rocky Point Hatchery staff and volunteers from the Merimbula Fishing Club for their assistance during the study. We also acknowledge the 3 anonymous reviewers and the 3 anonymous thesis examiners whose comments greatly improved the quality of this manuscript.

\section{LITERATURE CITED}

Addison JT, Bannister RCA (1994) Re-stocking and enhancement of clawed lobster stocks: a review. Crustaceana 67 : 131-155

Araki H, Schmid C (2010) Is hatchery stocking a harm or a 
help? Evidence limitations and future directions in ecological and genetic surveys. Aquaculture 308:S2-S11

Araneda M, Pérez EP, Gasca-Leyva E (2008) White shrimp Penaeus vannamei culture in freshwater at three densities: condition state based on length and weight. Aquaculture 283:13-18

Bell JD, Rothlisberg PC, Munro JL, Loneragan NR, Nash WJ, Ward RD, Andrew NL (eds) (2005) Restocking and stock enhancement of marine invertebrate fisheries. Adv Mar Biol 49:1-353

Bell JD, Bartley DM, Lorenzen K, Loneragan NR (2006) Restocking and stock enhancement of coastal fisheries: potential, problems and progress. Fish Res 80:1-8

Bell JD, Leber KM, Blankenship HL, Loneragan NR, Masuda R (2008) A new era for restocking, stock enhancement and sea ranching of coastal fisheries resources. Rev Fish Sci 16: $1-9$

Bishara NF (1976) Contributions to the biology of penaeid prawns in Lake Manzalah, Egypt. I. Growth studies and length-weight relationship. Aquaculture 8:337-349

Blankenship HL, Leber KM (1995) A responsible approach to marine stock enhancement. Am Fish Soc Symp 15: $167-175$

Cheng CS, Chen L (1990) Growth characteristics and relationships among body length, body weight and tail weight of Penaeus monodon from a culture environment in Taiwan. Aquaculture 91:253-263

Choquenot D (1991) Density-dependent growth, body condition and demography in feral donkeys: testing the food hypothesis. Ecology 72:805-813

Coles RG, Greenwood JG (1983) Seasonal movement and size distribution of three commercially important Australian prawn species (Crustacea, Penaeidae) within an estuarine system. Aust J Mar Freshw Res 34:727-743

Courtney AJ, Cosgrove M, Mayer D, Vance DJ (2002) Developing indicators of recruitment and effective spawner stock levels in eastern king prawns (Penaeus plebejus). Queensland Department of Primary Industries, Brisbane

> Crowl TA, Townsend CR, McIntosh AR (1992) The impact of introduced brown and rainbow trout on native fish: the case of Australasia. Rev Fish Biol Fish 2:217-241

Dall W, Hill BJ, Rothlisberg PC, Staples DJ (1990) The biology of the Penaeidae. Adv Mar Biol 27:1-489

- Davenport J, Ekaratne SUK, Walgama SA, Lee D, Hills JM (1999) Successful stock enhancement of a lagoon prawn fishery at Rekawa, Sri Lanka using cultured post-larvae of penaeid shrimp. Aquaculture 180:65-78

Eggleston DB, Johnson EG, Kellison GT, Plaia GR, Huggett CL (2008) Pilot evaluation of early juvenile blue crab stock enhancement using a replicated BACI design. Rev Fish Sci 16:91-100

Einum S, Fleming IA (2001) Implications of stocking: ecological interactions between wild and released salmonids. Nord J Freshw Res 75:56-70

Enin U (1994) Length-weight parameters and condition factor of two West African prawns. Rev Hydrobiol Trop 27: $121-127$

Farmer A (1981) A review of crustacean marking methods with particular reference to penaeid shrimp. Kuwait Bull Mar Sci 2:167-183

Filbert RB, Hawkins CP (1995) Variation in condition of rainbow trout in relation to food, temperature, and individual length in the Green River, Utah. Trans Am Fish Soc 124: 824-835

Froese R (2006) Cube law, condition factor and weight-length relationships: history, meta-analysis and recommendations. J Appl Ichthyol 22:241-256
Gab-Alla AAFA, Hartnoll RG, Ghobashy AF, Mohammed SZ (1990) Biology of penaeid prawns in the Suez Canal lakes. Mar Biol 107:417-426

Garcia-Berthou E, Moreno-Amich R (1993) Multivariate analysis of covariance in morphometric studies of the reproductive cycle. Can J Fish Aquat Sci 50:1394-1399

Gillooly JF, Brown JH, West GB, Savage VM, Charnov EL (2001) Effects of size and temperature on metabolic rate. Science 293:2248-2251

Griffiths SP (1999) Effects of lunar periodicity on catches of Penaeus plebejus (Hess) in an Australian coastal lagoon. Fish Res 42:195-199

> Hamasaki K, Kitada S (2006) A review of kuruma prawn Penaeus japonicus stock enhancement in Japan. Fish Res 80:80-90

> Haywood MDE, Staples DJ (1993) Field estimates of growth and mortality of juvenile banana prawns (Penaeus merguiensis). Mar Biol 116:407-416

Hilborn R (2007) Reinterpreting the state of fisheries and their management. Ecosystems 10:1362-1369

Hilborn R, Eggers D (2000) A review of the hatchery programs for pink salmon in Prince William Sound and Kodiak Island, Alaska. Trans Am Fish Soc 129:333-350

Hill BJ, Wassenberg TJ (1993) Why are some prawns found in seagrass? An experimental study of brown (Penaeus esculentus) and grooved ( $P$. semisulcatus) tiger prawns. Mar Freshw Res 44:221-227

Ihaka R, Gentleman R (1996) R: a language for data analysis and graphics. J Comput Graph Statist 5:299-314

> Ives MC, Scandol JP (2007) A Bayesian analysis of NSW eastern king prawn stocks (Melicertus plebejus) using multiple model structures. Fish Res 84:314-327

Jackson EL, Rowden AA, Attrill MJ, Bossey SJ, Jones MB (2001) The importance of seagrass beds as a habitat for fishery species. Oceanogr Mar Biol Annu Rev 39: 269-303

Kenyon RA, Loneragan NR, Hughes JM, Staples DJ (1997) Habitat type influences the microhabitat preference of juvenile tiger prawns (Penaeus esculentus Haswell). Estuar Coast Shelf Sci 45:393-403

Keough MJ, Downes BJ (1982) Recruitment of marine invertebrates: the role of active larval choices and early mortality. Oecologia 54:348-352

Kitting CL, Fry B, Morgan MD (1984) Detection of inconspicuous epiphytic algae supporting food webs in seagrass meadows. Oecologia 62:145-149

> Kneib RT (1987) Predation risk and use of intertidal habitats by young fishes and shrimp. Ecology 68:379-386

Kurata H (1981) Shrimp fry release techniques in Japan, with special reference to the artificial tideland. Bull Mar Sci 2: 117-147

Leber KM (2002) Advances in marine stock enhancement: shifting emphasis to theory and accountability. In: Stickney RR, McVey JP (eds) Responsible marine aquaculture. CABI Publishing, Wallingford, p 79-89

Leber KM, Arce SM (1996) Stock enhancement in a commercial mullet, Mugil cephalus L., fishery in Hawaii. Fish Manage Ecol 3:261-278

Liu H (1990) Resource enhancement of Chinese shrimp, Penaeus orientalis. Bull Mar Sci 47:124-133

Loneragan NR, Kenyon RA, Haywood MDE, Staples DJ (1994) Population dynamics of juvenile tiger prawns (Penaeus esculentus and P. semisulcatus) in seagrass habitats of the western Gulf of Carpentaria, Australia. Mar Biol 119:133-143

> Loneragan NR, Bunn SE, Kellaway DM (1997) Are mangroves and seagrasses sources of organic carbon for penaeid 
prawns in a tropical Australian estuary? A multiple stableisotope study. Mar Biol 130:289-300

Loneragan N, Crocos PJ, Barnard R, McCulloch R, Penn JW, Ward R, Rothlisberg P (2004) An approach to evaluating the potential for stock enhancement of brown tiger prawns (Peneaus esculentus Haswell) in Exmouth Gulf, Western Australia. In: Leber K, Kitada S, Blankenship HL, Svåsand $\mathrm{T}$ (eds) Stock enhancement and sea ranching: developments, pitfalls and opportunities. Blackwell, Oxford, p 444-464

Loneragan NR, Ye Y, Kenyon RA, Haywood MDE (2006) New directions for research in prawn (shrimp) stock enhancement and the use of models in providing directions for research. Fish Res 80:91-100

Ludwig D, Hilborn R, Waters C (1993) Uncertainty, resource exploitation, and conservation: lessons from history. Science 260:17-36

McEachron LW, Colura RL, Bumguardner BW, Ward R (1998) Survival of stocked red drum in Texas. Bull Mar Sci 62: 359-368

- Meretsky VJ, Valdez RA, Douglas ME, Brouder MJ, Gorman OT, Marsh PC (2000) Spatiotemporal variation in the length-weight relationship of endangered humpback chub: implications for conservation and management. Trans Am Fish Soc 129:419-428

Montgomery SS (1990) Movements of juvenile eastern king prawns, Penaeus plebejus, and identification of stock along the east coast of Australia. Fish Res 9:189-208

Moriarty DJW (1977) Quantification of carbon, nitrogen and bacterial biomass in the food of some penaeid prawns. Mar Freshw Res 28:113-118

Murphy BR, Willis DW, Springer TA (1991) The relative weight index in fisheries management: status and needs. Fisheries 16:30-38

NSW Department of Natural Resources (2000) Estuaries in NSW. NSW Department of Natural Resources, Sydney. Available at www.dnr.nsw.gov.au/estuaries/inventory/ index_az.shtml

> Ochwada F, Loneragan NR, Gray CA, Suthers IM, Taylor MD (2009) Complexity affects habitat preference and predation mortality in postlarval Penaeus plebejus: implications for stock enhancement. Mar Ecol Prog Ser 380:161-171

Ochwada-Doyle FA, Gray CA, Loneragan NR, Taylor MD (2010) Using experimental ecology to understand stock enhancement: Comparisons of habitat-related predation on wild and hatchery-reared Penaeus plebejus Hess. J Exp Mar Biol Ecol 390:65-71

Okayi G, Ataguba G, Nyishagba O (2010) Biology of two freshwater prawns (Palaeomonetes africanus and Demoscaris bislineata) from the MU River, Makurdi-Benue State, Nigeria. J Anim Plant Sci 5:544-549

Orth RJ, Heck KL, van Montfrans J (1984) Faunal communities in seagrass beds: a review of the influence of plant structure and prey characteristics on predator-prey relationships. Estuaries 7:339-350

Pérez-Castañeda R, Defeo O (2002) Morphometric relationships of penaeid shrimps in a coastal lagoon: spatio-temporal variability and management implications. Estuaries 25: 282-287

Ponce-Palafox J, Martinez-Palacios CA, Ross LG (1997) The effects of salinity and temperature on the growth and survival rates of juvenile white shrimp, Penaeus vannamei, Boone, 1931. Aquaculture 157:107-115

> Primavera JH, Parado-Estepa FD, Lebata JL (1998) Morphometric relationship of length and weight of giant tiger prawn Penaeus monodon according to life stage, sex and source. Aquaculture 164:67-75
Quinn G, Keough M (2002) Experimental design and data analysis for biologists. Cambridge University Press, Port Melbourne

Reid DD, Montgomery SS (2005) Creel survey based estimation of recreational harvest of penaeid prawns in four southeastern Australian estuaries and comparison with commercial catches. Fish Res 74:169-185

Rochet MJ (2000) May life history traits be used as indices of population viability? J Sea Res 44:145-157

Rogers MW, Allen MS, Brown P, Hunt T, Fulton W, Ingram BA (2010) A simulation model to explore the relative value of stock enhancement versus harvest regulations for fishery sustainability. Ecol Model 221:919-926

Rothlisberg PC (1998) Aspects of penaeid biology and ecology of relevance to aquaculture: a review. Aquaculture 164: 49-65

Rothlisberg PC, Church JA, Fandry CB (1995) A mechanism for near-shore concentration and estuarine recruitment of postlarval Penaeus plebejus Hess (Decapoda, Penaeidae). Estuar Coast Shelf Sci 40:115-138

Rothlisberg PC, Preston NP, Loneragan NR, Die DJ, Poiner IR (1999) Approaches to reseeding penaeid prawns. In: Howell BR, Moksness E, Svasand T (eds) Stock enhancement and sea ranching. Fishing News Books, Oxford, p 365-378

> Roy PS, Williams RJ, Jones AR, Yassini I and others (2001) Structure and function of south-east Australian estuaries. Estuar Coast Shelf Sci 53:351-384

> Ruello NV (1975) Geographical distribution, growth and breeding migration of eastern Australian king prawn Penaeus plebejus Hess. Aust J Mar Freshw Res 26:343-354

> Staples DJ, Heales DS (1991) Temperature and salinity optima for growth and survival of juvenile banana prawns Penaeus merguiensis. J Exp Mar Biol Ecol 154:251-274

Su M, Liao IC (1999) Research and development of prawn stock enhancement in Taiwan. In: Howell BR, Moksness E, Svasand $\mathrm{T}$ (eds) Stock enhancement and sea ranching. Fishing News Books, Oxford, p 379-392

> Suthers IM (1984) Functional morphology of the mouthparts and gastric mill in Penaeus plebejus Hess (Decapoda: Penaeidea). Aust J Mar Freshw Res 35:785-792

Suthers I (1998) Bigger? Fatter? Or is faster growth better? Considerations on condition in larval and juvenile coralreef fish. Aust J Ecol 23:265-273

Taylor MD (2010) Marine stocking in Victoria - a preliminary assessment of the potential suitability of Victorian waters selected for fish releases. UNSW Global, Sydney

> Taylor MD, Fielder DS, Suthers IM (2009) Growth and viability of hatchery-reared Agyrosomus japonicus released into open and semi-closed systems. Fish Manage Ecol 16: 478-483

Teikwa ED, Mgaya YD (2003) Abundance and reproductive biology of the penaeid prawns of Bagamoyo coastal waters, Tanzania. West Indian Ocean J Mar Sci 2:117-126

> Thomas SN, Edwin L, George VC (2003) Catching efficiency of gill nets and trammel nets for penaeid prawns. Fish Res 60:141-150

Travis J, Coleman FC, Grimes CB, Conover D, Bert TM, Tringali M (1998) Critically assessing stock enhancement: An introduction to the Mote Symposium. Bull Mar Sci 62: 305-311

Underwood AJ (2002) Experiments in ecology. Cambridge University Press, Cambridge

> Vance DJ, Pendrey RC (2008) Vertical migration of postlarval penaeid prawns in two Australian estuaries: the effect of tide and day/night. Mar Freshw Res 59:671-683

> Wang Q, Zhuang Z, Deng J, Ye Y (2006) Stock enhancement and translocation of the shrimp Penaeus chinensis in 
China. Fish Res 80:67-79

Wassenberg TJ, Hill BJ (1987) Natural diet of the tiger prawns Penaeus esculentus and $P$. semiesculentus. Aust J Mar Freshwater Res 38:169-182

$>$ Wassenberg TJ, Hill BJ (1994) Laboratory study of the effect of light on the emergence behaviour of eight species of commercially important adult penaeid prawns. Mar Freshw Res 45:43-50

Young PC (1975) Preliminary observations on the environment and biology of the juvenile king prawn (Penaeus

Editorial responsibility: Megan La Peyre,

Baton Rouge, Louisiana, USA plebejus) in Moreton Bay, Australian Government Public Service, Canberra

Young PC (1978) Moreton Bay, Queensland: nursery area for juvenile penaeid prawns. Aust J Mar Freshw Res 29:55-75

Young PC, Carpenter SM (1977) Recruitment of post-larval penaeid prawns to nursery areas in Moreton Bay, Queensland. Aust J Mar Freshw Res 28:745-773

Zeimann DA (2003) Enhancement of Pacific threadfin Polydactylus sexflis in Hawaii: interactions between aquaculture and fisheries. Oceanic Institute, Honolulu, HI

Submitted: March 3, 2011; Accepted: May 27, 2011

Proofs received from author(s): June 29, 2011 